\title{
SCHOLA LUDUS
}

\author{
Boris Aberšek \\ University of Maribor, Slovenia
}

The technology opens the door, but we, must decide if we will enter or not!

The virtual reality, artificial intelligence and gamification have the potential to complement existing educational approaches to science education, instruction and students' knowledge construction. By students becoming part of a phenomenon, they gain direct experiential intuitions about how the natural world operates. In a virtual reality environment, students themselves can be moving, cantering their attention on different phenomena and designers can heighten this saliency by using multisensory cues to convey multiple, simultaneous representations of relative problems as a serious mind game.

But let's start from the beginning. In ancient Roman and Greek culture, the word ludus has several meanings within semantic field of: play, games, sport, training (Oxford Latin Dictionary, 1985). Latin poetry often explores the concept of ludus as a playfulness. But the word ludus is also closely connected with ancient education. One of the first, who mentioned play in education has been Plato. Plato in ancient Greek culture shows how the philosopher's views on play can be best appreciated against the background of shifting meanings and evaluations of play in classical Greece. Plato proposed to regulate play for social ends, he seemed to suggest that intellectual play in some form, as demonstrated in the dialectical banter of Socrates, could provide a stimulus to understanding (Plato, 360 B.C). His work in many other areas continues his scholar Aristotle. In a famous passage of his Politics (Book 8 : 223-239) (Aristotle, 2013), Aristotle notes the historical connection between leisure and the growth of learning: "As wealth provided more leisure, the Greeks became more open-minded about areas in which they might seek competence. They had already been so in the pre-war period, but because they were riding high after their victories in the Persian Wars they got into all kinds of new disciplines. Nothing was too recherché: they continually sought out new areas of study and consequently brought even aulos [Greek reed instrument-ed.] playing into the curriculum." (Aristotle, 2013: 223-239, D'Angour, 2013: 301)

Despite the connections implied here between learning and play (mostly music), Aristotle thought of education as completely separate from play, arguing that education is a way to spend leisure-time edifyingly, whereas play is nothing more than a break from work: "We should ask what activity real leisure (schol) consists of. It's certainly not playing. That would mean play was the be-all and end-all of life, which is out of the question. The fact is that play relates to work more than to leisure: the worker needs a break, and play is about taking a break from work, while leisure is the antithesis of work and exertion." Aristotle's reduction of work and play to a dichotomy may account for why the new understanding of play as educational activity for children, broached by Plato's novel theorizing, disappeared from ancient thinking. It was not to be revived for over two millennia. (Plato, 360 B.C.: Book 6, D’Angour, 2013)

If we jump from ancient time to the time of illumination in Renaissance, in between nothing really interesting happened in the area of education, we can observe how great educational pioneers created their own educational philosophies. We will narrow our observation only on the naturalistic educators, who believed children were innately good. These pioneering educators as Komenský ${ }^{1}(1913,1896)$, Rousseau (1911), Pestalozzi (1894), Spencer (1911),

1 Komenský - the English translation is Commenius, but we will point out their Czech (and Central European) roots and use original name Jan Amos Komenský 
Locke (2007), Dewey (1915) and many others came to be called naturalistic because they believe children learned most effectively and efficiently by examining objects in their immediate natural environment where deliberate efforts to create learning situations that would respect and utilize the children's own process of development. Komenský occupied a middle position between the Renaissance humanist educators and later naturalistic reformers as Rousseau, Pestalozzi and Spencer. Komenský points out that children learn most efficiently when they are ready for particular kind of learning: children should not be hurried, coerced, or pressured to learn. Thus, Komenský advised teachers to organize lessons into easily assimilated steps to make learning gradual, cumulative and pleasant. (Smolik, 1987) Komenský well-known motto is Schola ludus (school as a play). He emphasized the function of a play as a pedagogically effective activity (Komenský, 1913, 1896).

But what does it mean play and consequently schola ludus today, in a modern teaching/learning process? In psychology, cognitive science, play is a range of voluntary, intrinsically motivated activities normally associated with recreational pleasure and enjoyment (Garvey, 1990). Many prominent researchers in the field of psychology, including Jean Piaget (1962), Carl Jung (1987) and Lev Vygotsky (2011) have viewed play as confined to the human species, believing play was important for human development and using different research methods to prove their theories. Various forms of play, whether it is physical or mental, have influenced cognitive abilities in individuals. Play can also influence one's social development and social interactions. So, nowadays, the old Komenský motto schola ludus has found its modern use in interactive educational programs using play and games as a pedagogical tool in the form of serious mind games and simulation games. By means of a simulation game it is possible to test, without any risk, the simulated object's behaviour. Intelligent serious games are simulations of real-world events or processes designed for the purpose of solving a problem, a real problem in real situation (for example, big bang process, how things work, the happenings in nano world, etc.), with interaction with outside world via different sensors. Although serious mind games can be entertaining, their main purpose is to train or educate users. Serious intelligent mind games will sometimes deliberately sacrifice fun and entertainment in order to achieve a desired educational progress by the player. Serious intelligent mind games are not a game genre but a category of games with different purposes (educational goals).

\section{New Paradigm of Teaching/Learning}

If we would like to use games, intelligent serious games as a tool in education, educators must drastically change the way of thinking and teaching. They must start talking about transdisciplinarity (Flogie, Aberšek, 2015), about competences (Pešakovič, Flogie, Aberšek, 2014), about competence based curriculum and about innovative methods in education (Kordigel Aberšek, Dolenc, Kovačič, 2015). The novel perspective of oneself experiencing and shaping a natural phenomenon, instead of acting as a passive observer, is intrinsically motivating. Transducing data and abstract concepts into multisensory representations is also a powerful means of enhancing understanding. Under these conditions, learners may be able to construct mental models of phenomena that have no counterpart in their everyday experience. They must change the old traditional way of learning into a new one as a game based learning (GBL) and gamification.

The gamification of learning is an educational approach to motivate students to learn by using game elements in learning environments. The goal of introducing gamification in education is to maximize enjoyment and engagement through capturing the interest (motivation) of learners and inspiring them to continue learning. Game-based learning $(G B L)$ is a type of game play that has defined learning outcomes. Generally, game-based learning is designed to balance subject matter with gameplay and the ability of the player to retain, and apply the subject matter to the real world. In a successful game-based learning environment, choosing actions, experiencing consequences, and working toward goals allows players to make mistakes through experimentation in a risk-free environment (Pavlus, 2010). Before deciding how to use game-based learning, the teacher must first determine what he would like the students to learn. A teacher that fails to focus teaching around a central idea runs the risk of using a game that fails to connect with the students. To prevent this, teacher must tailor the material so that the material is neither too difficult for, nor too familiar to the students. Also Student's early involvement in requirements is important for individualization and differentiation of the learning process (Walz, Deterding, 2014).

A new paradigm of teaching and new technologies are at the gates of school and we (teachers), will have to follow this trend, if we wanted or not. If so, use them for the good of the students in the most effective way. 


\section{References}

Aristotle (2013). Politics. Chicago: The University Chicago Press.

Comenius, J. A. (1896). Great Didactica of John Amus Comenius. New York: Russell \& Russell

D'Angour, A. (2013). Plato and play, taking education seriously in Ancient Greece. American Journal of Play, 5 (3), 293-307.

Dewery, J. (1915). The school and society. Chicago, Illinois: The University of Chicago press.

Flogie, A., Aberšek, B. (2015). Transdisciplinary approach of science, technology, engineering and mathematics education. Journal of Baltic Science Education, 14 (6), 779-790.

Garvey, C. (1990). Play. Cambridge, MA: Harvard University Press.

Jung, C. G. (1987). Dictionary of analytical psychology. London: Ark Paperbacks.

Komensky, J. A. (1913). Ve kere Spisy Jana Amusa Komenského Didactica Magna. Brno: NUSJUNM

Kordigel-Aberšek, M., Dolenc, K., Kovačič, D. (2015). Elementary and natural science teachers' online reading metacognition. Journal of Baltic Science Education, 14 (1), 121-130.

Locke, J. (2007). Some thoughts concerning education. Mineola, New York: Dover Publications, Inc.

Oxford Latin Dictionary (1985). (Oxford: Clarendon Press, 1048-1049.

Pavlus, J. (2010). The game of life. Scientific American, 303, 43-44.

Pestalozzi, J. H. (1894). How Gertrude teaches her children. London: Swan Sonnenschein.

Pešakovič, D., Flogie, A., Aberšek, B. (2014). Development and evaluation of a competence-based teaching process for science and technology education. Journal of Baltic Science Education, 13 (5), 740-755.

Piaget, J. (1962). Play, dreams and imitation in childhood. New York: Norton.

Plato (360 B.C.). The Republic:Book VI. Free eBooks by project Gutenberg: Retrieved: http://www.gutenberg.org/files/1497/1497h/1497-h.htm.

Rousseau, J. J. (1911). Emile, or education. London \&Toronto: J. M. Dent \& Sohns Ltd. \& E.P. Dutton\&Co.

Smolik, J. (1987). Comenius: A man of hope in a time of turmoil. Christian History, 6, 15-18.

Spencer, H. (1911). Essays on education and kindred subjects. London: Dent.

Vygotskij, L. S. (2011). Vorlesungen über Psychologie [Lectures on Psychology]. Berlin: Lehmanns Media.

Walz, S. P., Deterding, S. (2014). The gameful world: Approaches, issues, applications. Cambridge: MIT Press. 